\title{
Tissue Proportion, Fibre, and Vessel Characteristics of Young Eucalyptus Hybrid Grown as Exotic Hardwood for Wood Utilization
}

\author{
James Kudjo GovinA ${ }^{\text {a c* }}$ - Emmanuel EBANYENLE ${ }^{\mathrm{a}}-$ \\ Emmanuel APPIAH-KUBI ${ }^{\mathrm{b}}-$ Francis Wilson OWUSU $^{\mathrm{a}}-\mathrm{James}^{\mathrm{K}} \mathrm{KORANG}^{\mathrm{a}}-$ \\ Haruna SEIDU ${ }^{\mathrm{a}}$ - Róbert NÉMETH ${ }^{\mathrm{c}}$ - Roland Walker MENSAH ${ }^{\mathrm{a}}-$ Ruth AMUZU $^{\mathrm{a}}$ \\ ${ }^{\text {a }}$ CSIR- Forestry Research Institute of Ghana, Kumasi, Ghana \\ ${ }^{\mathrm{b}}$ Department of Construction and Wood Technology, University of Education, Kumasi, Ghana \\ ${ }^{\mathrm{c}}$ Institute of Wood Technology and Technical Sciences, Faculty of Wood Engineering and Creative Industries, \\ University of Sopron, Sopron, Hungary
}

\begin{abstract}
This study sought to determine selected anatomical properties of young Eucalyptus hybrid species (E. grandis $x$ E. urophylla) grown in Ghana. Images of fibres from macerated wood, and micro-sections produced with microtome were analysed using a compound digital microscope associated with Motic Image Plus Software (MIPS), version 2.0, installed on a computer. Images were initially processed using ImageJ software. Study data were analysed using an R statistical package. The overall mean value for fibre length was $907.67 \mu \mathrm{m}$, whereas double fibre wall thickness was 7.76 $\mu \mathrm{m}$. Both variables had higher mean values in sapwood than in heartwood. Nevertheless, the found values decreased from the butt to the top portion. Statistically, axial and radial positions had no influence on fibre characteristics. In a $1 \mathrm{~mm}^{2}$ of the cross-section, the proportion of fibres was $38 \%$, vessels were $19 \%$, axial parenchyma were $22 \%$, and radial parenchyma were $21 \%$ on average. Again, the radial and axial positions had no statistical influence on tissue proportion traits for the young eucalyptus wood. Mean value for vessel area was $9462.04 \mu \mathrm{m}^{2}$, whereas vessel frequency per $\mathrm{mm}^{2}$ was about 14 . Vessels were significantly larger in area (range $9982.50-13544.41 \mu \mathrm{m}^{2}$ ), yet reduced in frequency (range 6-17 per $\mathrm{mm}^{2}$ ) for sapwood. In heartwood, vessel area was comparatively smaller (range $6321.15-7816.69 \mu \mathrm{m}^{2}$ ), whereas their frequency was high (range $15-18$ vessels per $\mathrm{mm}^{2}$ ). Axial and radial position had statistical influence on vessel frequency and area for the young Eucalyptus grown in a plantation in Ghana.
\end{abstract}

Eucalyptus / hybrid / fibre / tissue / parenchyma / vessel

Kivonat - Fahasznosítás céljából termesztett Eucalyptus hibrid fajok fiatal egyedeinek szöveti szerkezete, rost- és edényjellemzői. Ez a cikk a Ghánában termesztett Eucalyptus hibrid fajok $(E$. grandis $x$ E. urophylla) fiatal egyedeinek egyes anatómiai tulajdonságait írja le. A macerációval elkülönített farostok fotóit, ill. mikrotómmal készített anatómiai metszetek mikroszkopikus részleteit elemeztük egy összetett digitális mikroszkóppal, amely a számítógépre telepített Motic Image Plus Software (MIPS) 2.0 verziójához kapcsolódott. A képeket eredetileg ImageJ szoftverrel dolgoztuk fel. A nyert adatokat R statisztikai szoftvercsomag segítségével elemeztük. A rosthossz átlagértéke 907,67 $\mu \mathrm{m}$, míg a kettős sejtfalfalvastagság 7,76 $\mu \mathrm{m}$ volt. Megállapítottuk, hogy a szijács hosszabb farostokat

*Corresponding author: ndvm36@uni-sopron.hu; H-9400 SOPRON, Bajcsy-Zs. u. 4, Hungary 
tartalmaz, melyeknek kettős falvastagsága is nagyobb a gesztben mért értékekhez viszonyítva, ugyanakkor a különbségek statisztikailag nem szignifikánsak. Az említett értékek a tő felől a csúcs irányában csökkenő értékeket mutattak, de statisztikailag nem volt igazolható az eltérés. Statisztikailag tehát az axiális és radiális helyzetek nem befolyásolták a farostok jellemzöit. $1 \mathrm{~mm}^{2}$ keresztmetszetet vizsgálva a farostok aránya $38 \%$, az edényeké $19 \%$, az axiális parenchimáké $22 \%$, míg a bélsugár parenchimáké $21 \%$. A radiális és axiális helyzetnek nincs statisztikai hatása a fiatal eukaliptusz faegyedekben a vizsgált sejttípusok arányára. Az edényterület átlagos értéke $9462,04 \mu \mathrm{m}^{2}$ volt, míg az edények darabszáma 14 körüli érték volt $1 \mathrm{~mm}^{2}$-re vetítve. A szijácsban az edények területe a 9982,50 - 13544,41 $\mu \mathrm{m}^{2}$ tartományban, mozgott, de darabszámuk kisebb volt a geszthez viszonyítva $(6-17$ $\left.\mathrm{db} / \mathrm{mm}^{2}\right)$. A gesztben az edények területe kisebb értéket adott $\left(6321,15-7816,69 \mu \mathrm{m}^{2}\right)$, míg darabszámuk nagyobb volt $\left(15-18 \mathrm{db} / \mathrm{mm}^{2}\right)$. Vizsgálatainkkal megállapítottuk, hogy a ghánai ültetvényen termesztett fiatal Eucalyptus egyedek esetén az axiális és a radiális helyzet statisztikailag befolyásolta az edények mennyiségét (számát) és méretét (területét).

Eukapliptusz / hibrid / farost / szöveti szerkezet / parenchyma / edény

\section{INTRODUCTION}

Wildfires, illegal logging, overexploitation to meet domestic and foreign wood demand, and other factors put continuous pressure on natural forests in tropical timber producing countries. Experts have predicted that the raw material base for wood will soon shift from natural to plantation timber. Efforts to guarantee a sustainable future supply of wood include the introduction of fast-growing exotic species like Tectona grandis, Cedrela odorata, and Eucalyptus species. The genus Eucalyptus comprises fast-growing species that are able to adapt well to marginal soils in diverse climatic conditions (Willan 1951, Woods - Peseta 1996). These characteristics make Eucalyptus a suitable candidate genus for commercial timber plantations that can meet the increasing wood demand as well as mitigate some alarming climate change effects. Eucalyptus plantations are found currently in tropical, subtropical, and temperate areas. They amount to $8 \%$ of planted forests globally (Harwood 2011).

Wood from Eucalyptus species are useful for pulp and paper, solid wood products, veneer, fuelwood, posts, etc. In Kenya, eucalyptus is the third most grown genus after pine and cypress. It was originally introduced in Kenya to provide biomass for powering railway steam engines (Githiomi - Kariuki 2010). Until recently, eucalyptus was only planted in small scale research plot sizes and on private lands in Ghana, primarily for shade and ornamental purposes. Admittedly, general information on original eucalyptus species has been published; however, specific research on young stems is scarce. Presently, MIRO Forestry Ghana Limited, a private organisation, has adopted a breeding technology program for Eucalyptus grandis and Eucalyptus urophylla. The goal is to create a hybrid species for an improved tree form and enhanced growth. Nonetheless, little research focusing on the wood properties has been completed on bred Eucalyptus species.

As is the case with other tree species, silvicultural management, age, genetics, and growing sites influence the formation and quality of the woody biomass of eucalyptus (Zobel - van Buijtenen 1989, Savidge 2003, Roque 2004). In addition, wood quality can also vary with an individual tree and between trees of same species growing under same conditions (Plomion et al. 2001, Wimmer et al. 2002, Monteoliva et al. 2005, Quilhó et al., 2006, Sharma et al. 2015).

Generally, it has been argued that timber species that are fast-growing and less than ten years old produce mostly juvenile, inferior quality wood (Zobel - Sprague 1998, Moore Cown 2017). Accordingly, properties of young eucalyptus wood need to be investigated for efficient utilization. The anatomical structure and characteristics of wood are known to 
influence the most important properties, which include density, drying characteristics, shrinkage, permeability for preservation treatment, pulp yield, paper strength, etc. (Fujiwara et al. 1991, Ofori - Brentuo 2005, Bhat et al. 2007, Yahya et al. 2010, Zanuncio et al. 2016). Moglia et al. (2008), reported that fibre and vessel length significantly varied radially within a tree, whereas tissue proportion differed considerably between trees of same species. Amidon (1981) and Barauna et al. (2014) found that vessel frequency and diameter size greatly affected papermaking properties and wood permeability. The present study aimed to establish the anatomical properties that are fundamental to enhancing the utilisation potential of hybrid Eucalyptus species grown in Ghana. Specific anatomical properties considered for the present study were fibre characteristics (length, diameter, lumen width, and wall thickness), tissue proportion (fibre, vessel, axial and radial parenchyma), and vessel characteristics (frequency and area). These variables could influence utilisation properties of the young wood considerably.

\section{MATERIALS AND METHODS}

\subsection{Study site}

The study was conducted with materials from a plantation site owned by MIRO Forestry Ghana Limited located near Agogo in Asante Akyem North district of the Ashanti region of Ghana (Figure 1). The land is a degraded forest reserve forming part of the forest transition zone of Ghana. Between 2013 and 2018, the district, which is located on latitude $6^{\circ} 37^{\prime} 5^{\prime \prime} \mathrm{N}$ and longitude $1^{\circ} 12^{\prime} 36^{\prime \prime} \mathrm{W}$, recorded monthly rainfall between $120 \mathrm{~mm}$ and $150 \mathrm{~mm}$. The mean temperature ranged between $26^{\circ} \mathrm{C}$ and $30^{\circ} \mathrm{C}$ (MOFA 2018). Total plot size was 50 hectares.

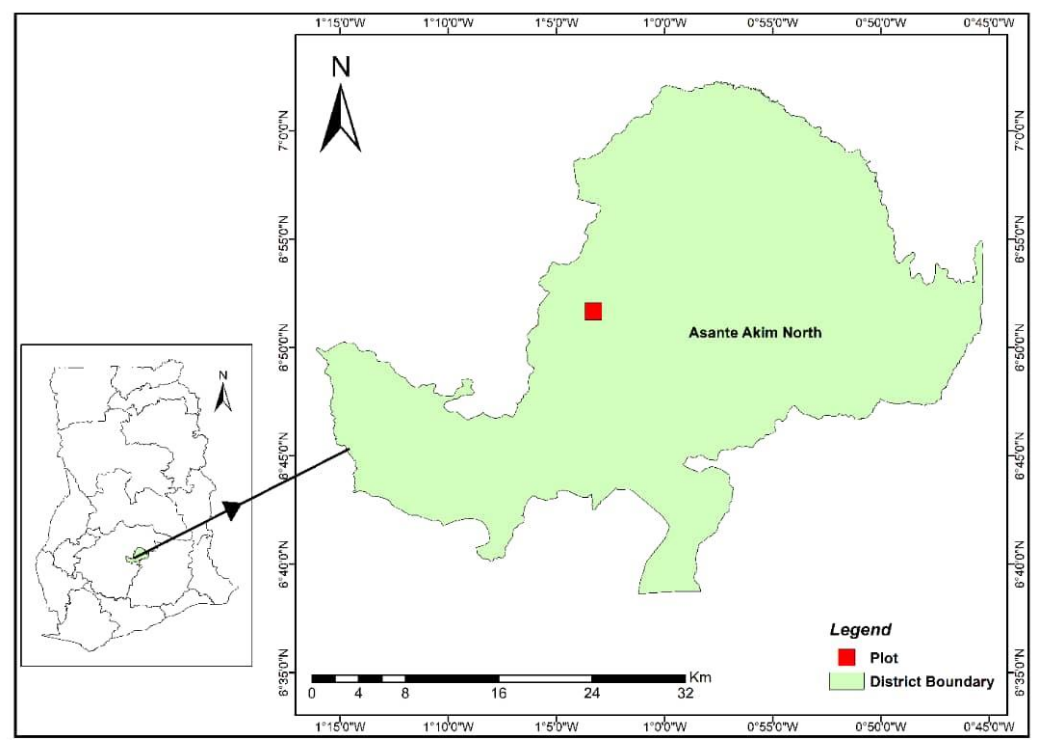

Figure 1. A map highlighting the Eucalyptus plot and Asante Akyem North District in the Ashanti region of Ghana.

\subsection{Measurement of trees morphological features}

The Eucalyptus hybrid (E. grandis and E. urophylla) trees were four years old, planted with $2.5 \times 3 \mathrm{~m}$ spacing, and were nurtured with MIRO's thorough silvicultural management and protection from annual wildfires. Fifty trees were randomly selected for height and diameter measurement. Diameter tape was used to measure stem diameters for the trees at breast height 
position of $1.3 \mathrm{~m}$. Tree heights were measured using a linear tape after the trees had been harvested close to the ground with a chainsaw. Respective stump heights were also added.

\subsection{Sampling of wood materials}

Six trees were randomly selected from the 50 harvested trees. MIRO donated only six trees for this destructive study. The trees were crosscut into three axial portions representing the butt, middle, and top position of tree. One $2 \mathrm{~cm}$-wide wood disc was collected from the different stem height levels (butt, middle, and top) of all six trees. Eighteen (18) wood discs were labelled accordingly. Each disc was packaged in a sealed polythene and transported to the Wood Anatomy Laboratory within the Council for Scientific and Industrial Research's Forestry Research Institute of Ghana (CSIR-FORIG). The idea behind sampling from the axial position was to address any inherent variability that had naturally developed during growth of each tree. Again, there was a sharp visible distinction between sapwood and heartwood on the butt and middle discs. Therefore, one sample from heartwood and one from sapwood were taken from either side of the disc (Cherelli 2015). A total of 72 sub-samples were studied (4 sub-samples x 18 discs).

\subsection{Fibre characteristics}

Matchstick-sized wood pieces were taken from all sub-samples. These were placed in labelled vials and macerated using a solution of equal parts of hydrogen peroxide and glacial acetic acid. The vials containing the wood material were kept in a $\mathrm{N} 53 \mathrm{C}-\mathrm{Genlab}$ Oven at $60^{\circ} \mathrm{C}$ and monitored every 12 hours until the maceration was complete. The macerate was repeatedly washed with distilled water to guarantee total removal of acetic acid (Franklin 1945). A drop of glycerol was placed unto the macerate, and the fibres were put on a specimen slide where they were separated apart with a pin (Figure 2). The slides were studied under a digital Compound Microscope (National) operated alongside a Motic Image Plus software (MIPS). Images with X40 magnification (Figure 2) were employed for the measurement of fibre length, whereas images with X400 magnification (Figure 3) were used for diameter, lumen width, and wall thickness. Twenty-five (25) straight and unbroken fibres were measured for each sub-sample. This resulted in 50 fibres for sapwood and 50 fibres for heartwood, for a total of 100 fibres per disc.

\subsection{Tissue proportion and vessel characteristics}

Wood samples of approximately $2 \mathrm{~cm}$ in all dimensions were taken through a softening process following published protocols (Schweingruber 2007). After being softened, each sample was mounted on a sledge Microtome (HM 400, Microm, Walldorf, Germany) to cut microsections of about $10-20 \mu \mathrm{m}$ from the cross-sectional surface (Figure 4). The thin sections were stained with safranin solution and further submitted to a gradual dehydration process. This was achieved by transferring the stained microsections from water through ethanol solution of $30 \%, 50 \%, 70 \%, 90 \%$, and absolute ethanol. Furthermore, the sections were permanently mounted with Canada balsam and oven-dried at $60{ }^{\circ} \mathrm{C}$ (Schweingruber 2007, Tardif - Conciatori 2015). The best-mounted sections were selected, at least 3 slides per sub-sample, and studied under the microscope associated with MIPS to capture images. In ImageJ, the software scale is set using the scale of an individual image. Afterwards, a scale grid of $1 \mathrm{~mm}^{2}$ was superimposed, at least 10 times, on original images representing a subsample. The individual tissue elements (fibre, vessel, axial parenchyma, radial parenchyma) within the $1 \mathrm{~mm}^{2}$ area were counted at each placement and equated to 20 . 


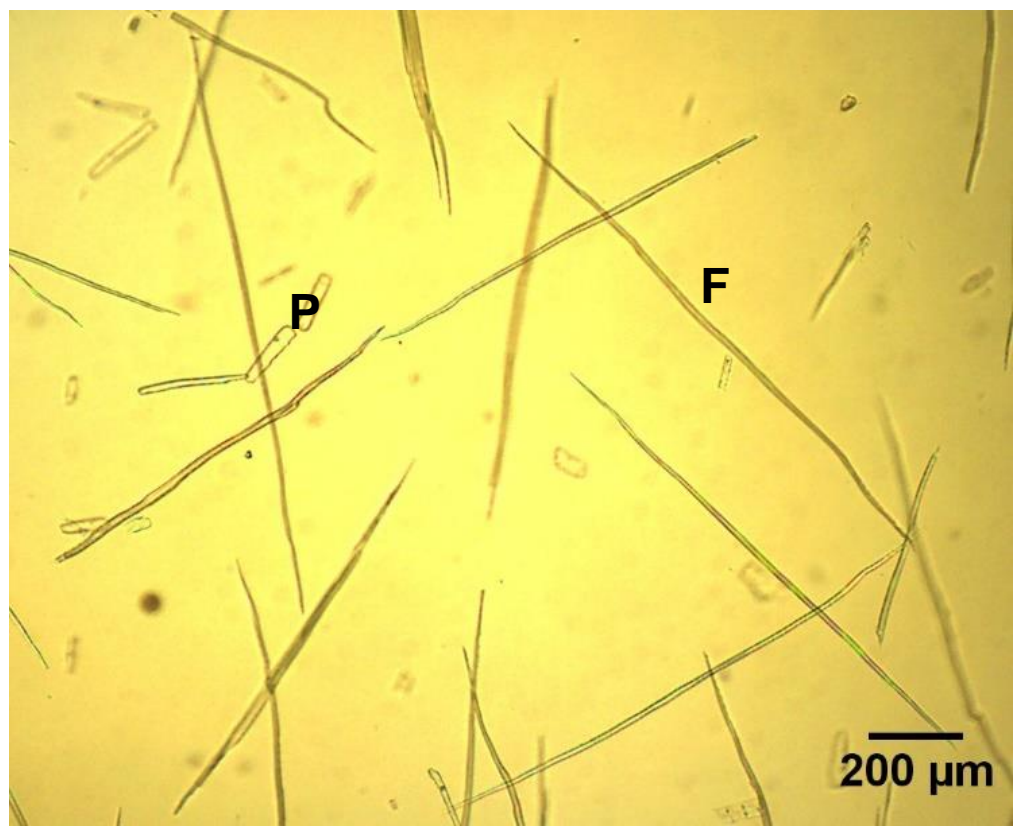

Figure 2. Fibres $(F)$ and parenchyma cells $(P)$ from macerated wood from 4-year-old Eucalyptus hybrid species grown in Ghana.

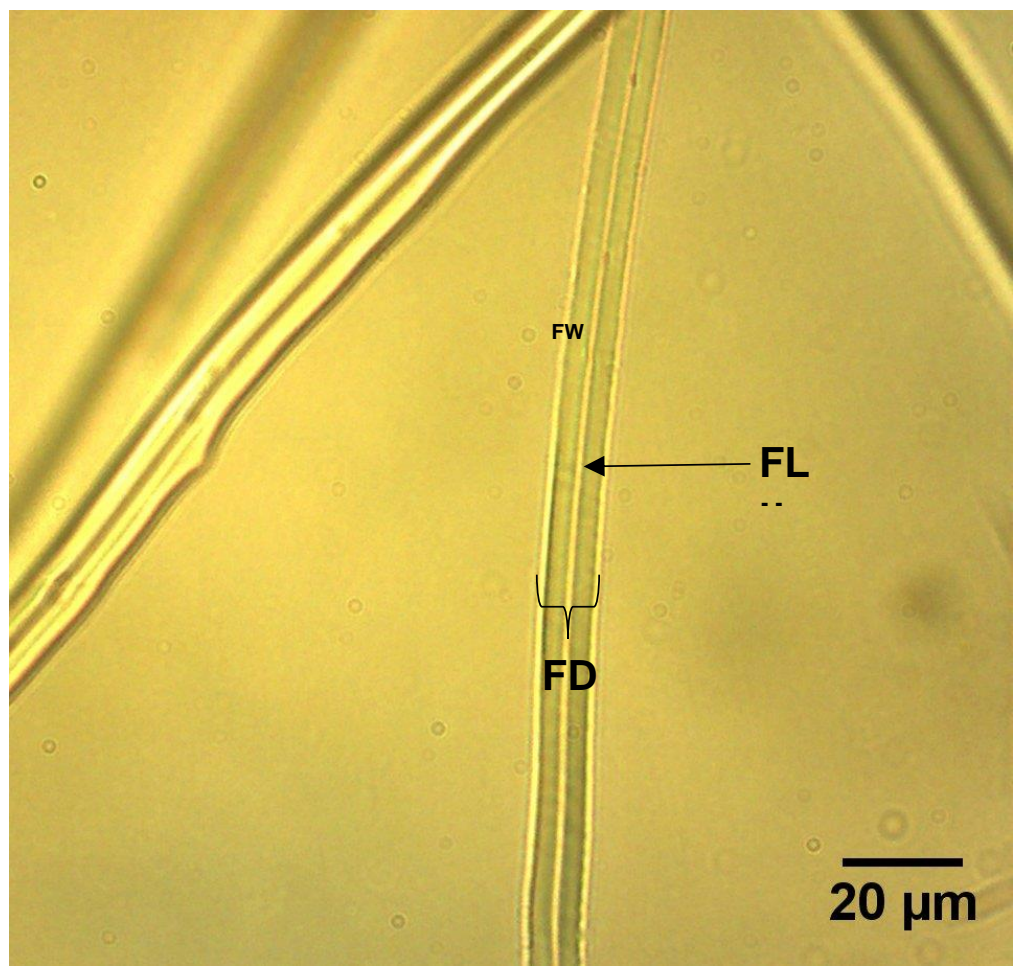

Figure 3. A magnified fibre from macerated wood from a 4-year-old Eucalyptus hybrid species. (FW): Fibre wall; (FD): Fibre diameter; (Flu): Fibre lumen.

For instance, if vessels are 3 out 20 spots, the proportional means are reported as percentages as $(3 / 20) \cdot 100$. Regarding vessel characteristics measurement, ImageJ software was used to analyse the same images captured to represent the sub-samples (Abràmoff et al. 2004). For vessel area, the images were converted into 8-bit format, inverted, and threshold set activated to convert all vessels into black dots. Using a feature called 'analyse particle' within ImageJ, 
dot circularity was set between 0.75-1.00. Furthermore, the desired dot area was set above a pre-determined area of the smallest vessel. This excludes the many smaller dots representing cells such as axial parenchyma. Vessels were analysed as particles to estimate their area (Figures 4 and 5). A minimum of 45 vessels from three different images were feasible for area measurement for each sub-sample. Vessel frequencies were completed manually on the same-sized images.

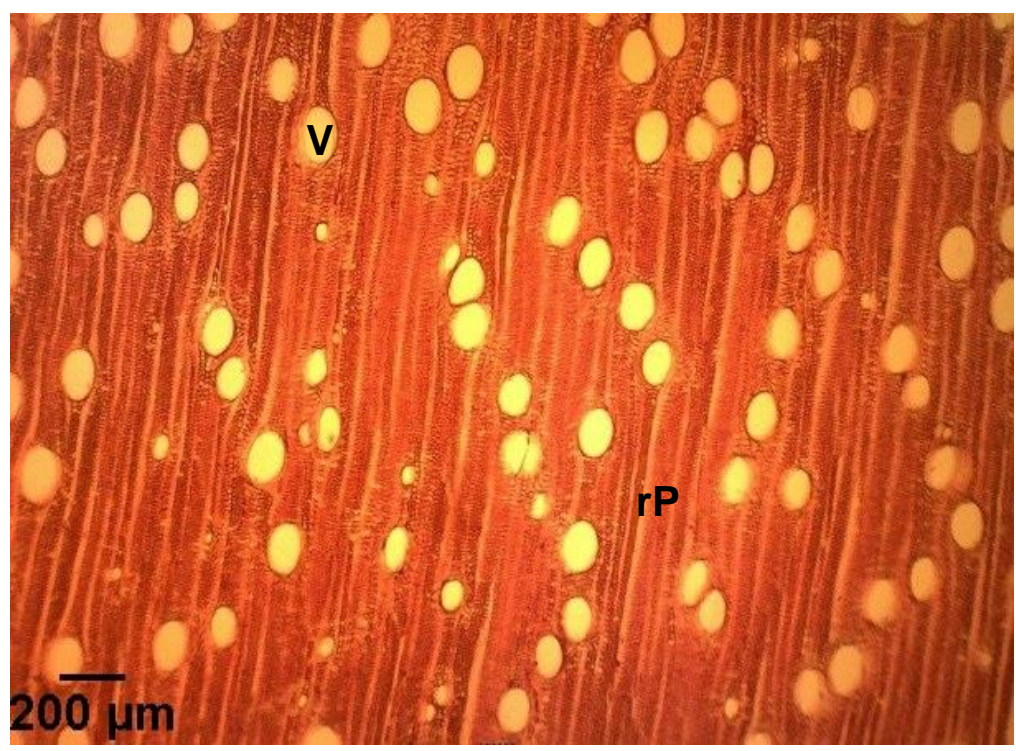

Figure 4. Cross-sectional image of wood from a 4-year-old Eucalyptus hybrid grown in Ghana. Image is at $X 40$ magnification. $V=$ vessel, $r P=$ radial parenchyma

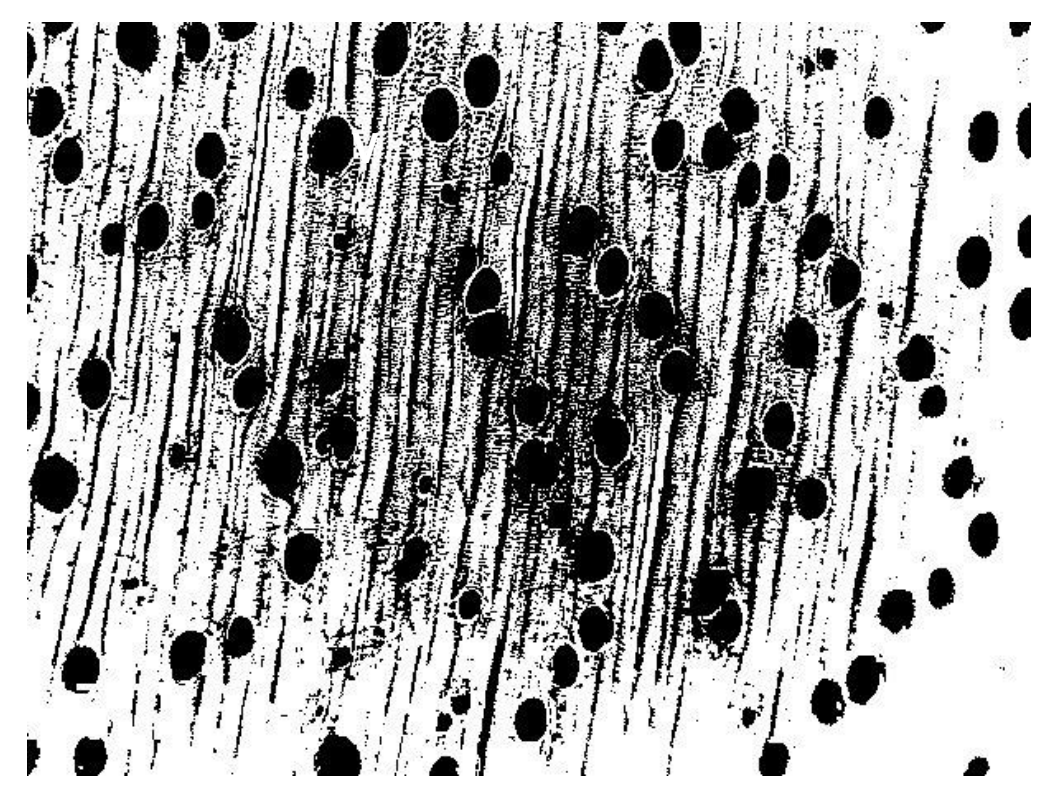

Figure 5. A processed image of a cross-section of wood from 4-year-old Eucalyptus hybrid species grown in Ghana. The vessels in the original image (Figure 4) are now seen as dark particles. Radial parenchyma now seen as black stripes.

\subsection{Data analysis}

The data generated from the study was organized with an Excel spreadsheet (Microsoft 365), and analysed using the $\mathrm{R}$ statistical package (Team 2014). The mean values and their corresponding standard deviations are reported in Tables 2-4. A one-way analysis of variance 
(ANOVA) was employed to test if differences observed in the mean values were statistically significant. $P$-values from ANOVA outputs are included in the Tables presented above. Tukey's Honest Significant Difference was implemented to compare mean values with statistically significant differences, especially for variables with more than two categories.

\section{RESULTS AND DISCUSSION}

In general, the study results of morphological features, tissue proportion, fibre and vessel traits were comparable among the axial and radial positions as well as to values reported in the literature.

\subsection{Morphological features}

Mean merchantable height was $14.26 \mathrm{~m}$, whereas the mean diameter at the butt section was $31.42 \mathrm{~cm}$ (Table 1). The mean height and diameters the present study found for eucalyptus trees grown in Ghana correspond with those reported in literature. In Brazil, Brito et al. (2019) reported a diameter at breast height $(\mathrm{dbh})$ of $16.19 \mathrm{~cm}$ and a height of $17.07 \mathrm{~m}$ for clone materials of the same age. Likewise, Ramalho et al. (2019) reported a dbh range of 7.4$14.11 \mathrm{~cm}$. Quilho et al. (2006) found an average dbh of $11.5 \mathrm{~cm}$ and an average commercial height of $17.8 \mathrm{~m}$ for 5-year-old Eucalyptus urograndis hybrid trees. The study results indicate that the hybrid eucalyptus trees have positively adapted to their growth conditions. It also suggests that Eucalyptus hybrid trees have sufficient crown development to provide adequate useful area for the trees (Miranda et al. 2009). The morphological findings reported in Table 1 are important when considering the utilization of 4-year-old materials for solid wood applications such as utility poles. The impregnation of preservatives and their retention are influenced by the sapwood portion (Valle et al. 2013).

Table 1. Some morphological properties for 4-year-old Eucalyptus hybrid trees (E. grandis $x$ E. urophylla) grown in Ghana. (Max): Maximum; (Min): Minimum; (Stdv): Standard Deviation. Total samples trees $(n)=50$.

\begin{tabular}{lclll}
\hline Variable & Min & Max & Mean & Stdv \\
\hline Merchantable length (m) & 11.55 & 16.87 & 14.26 & 2.20 \\
Butt diameter (cm) & 28.65 & 34.70 & 31.42 & 2.36 \\
Top diameter (cm) & 9.23 & 13.37 & 11.14 & 1.55 \\
Sapwood width at butt (mm) & 15 & 95 & 56 & 2.34 \\
Sapwood width 3m from butt (mm) & 37 & 76 & 53.50 & 1.58 \\
Sapwood width at mid-length (mm) & 40 & 60 & 47.83 & 0.78 \\
\hline
\end{tabular}

\subsection{Fibre biometry}

The mean fibre length for the eucalyptus hybrid trees was $907 \mu \mathrm{m}$. The found value falls within the length range $(800$ to $1300 \mu \mathrm{m})$ reported in an earlier study and the InsideWood database (Wheeler 2011, Brito et al. 2021). Fibre length decreased from tree butt to the top portion (938.81 to $862.69 \mu \mathrm{m})$ as shown in Table 2 .

The observed longitudinal variation agrees with other studies (Quilhó et al. 2006, Bhat et al. 2007). However, the abovementioned authors observed an initial increase in fibre length to about breast height before the decrease to the top portion. In the present study, the middle portion was at exactly the 50\% mark of merchantable height reported in Table 1. Clearly, the middle portion was beyond the breast height of $1.3 \mathrm{~m}$. Bamber (1985) reported a similar observation. Quilhó et al. (2006) studied eucalyptus hybrids (E. grandis and E. 
urophylla) and reported $820-1040 \mu \mathrm{m}$ for fibre length for trees from seed origin and 1010$1110 \mu \mathrm{m}$ for five-and-half-year-old clones. Regarding the same hybrid grown in India, Sharma et al. (2015) reported 910-1140 $\mu \mathrm{m}$ for fibre length. Radially, the sapwood had longer mean fibre length $(949.55 \mu \mathrm{m})$ than heartwood $(862.77 \mu \mathrm{m})$. The differences between mean values for fibre length, for both axial and radial positions, were statistically insignificant.

Table 2. $\quad$ Mean values of fibre characteristics for 4-year-old eucalyptus hybrid (E. grandis $x$ E. urophylla) grown in Ghana. (FL): Fibre Length; (FD): Fibre Diameter; (FLW): Fibre Lumen Width; (FDWT): Fibre Double Wall

Thickness.

\begin{tabular}{llcccc}
\hline Positions & Levels & FL $(\mu \mathrm{m})$ & FD $(\mu \mathrm{m})$ & FLW $(\mu \mathrm{m})$ & FDWT $(\mu \mathrm{m})$ \\
\hline Axial & Top & $862.69(81.85)$ & $16.85(1.82)$ & $9.67(1.11)$ & $7.18(1.07)$ \\
& Middle & $923.26(69.83)$ & $16.49(1.13)$ & $8.77(1.06)$ & $7.72(0.83)$ \\
& Butt & $938.81(77.86)$ & $17.98(1.51)$ & $9.56(1.33)$ & $8.42(1.92)$ \\
\cline { 2 - 6 }$P$-value & 0.22 & 0.24 & 0.38 & 0.31 \\
Overall mean & $907.67(40.25)$ & $17.11(0.78)$ & $9.33(0.49)$ & $7.77(0.62)$ \\
\hline \multirow{2}{*}{ Radial } & Heartwood & $862.77(82.86)$ & $17.71(1.33)$ & $10.23(1.50)$ & $7.49(1.16)$ \\
& Sapwood & $949.55(52.97)$ & $16.49(1.69)$ & $8.48(0.88)$ & $8.00(1.14)$ \\
\cline { 2 - 6 }$P$-value & 0.06 & 0.19 & 0.034 & 0.45 \\
Overall mean & $906.16(61.36)$ & $17.10(0.86)$ & $9.36(1.24)$ & $7.76(0.36)$
\end{tabular}

The P-values for each variable are from a one-way ANOVA run at $95 \%$ confidence interval. In parenthesis are the standard deviation of the mean values. Total sampled trees $(n)=6$.

Regarding fibre diameter (width), the mean value was $17.11 \mu \mathrm{m}$. This variable decreased from the butt to the middle, but slightly increased from the middle to the top portion (Table 2 ). The study finding on fibre diameter correlates with values reported in the literature. Carvalho and Nahuz (2001) reported $17.1 \mu \mathrm{m}$; Rao et al. (2002) reported $14.5-16.9 \mu \mathrm{m}$; Quilhó et al. (2006) reported $20 \mu \mathrm{m}$; Sharma et al. (2015) reported $14.3-16.8 \mu \mathrm{m}$. Across radial position, fibre diameter was higher in heartwood. The mean values for fibre diameter found by this study were not statistically different in either axial or radial directions.

The mean value of fibre double wall thickness (width) was $7.76 \mu \mathrm{m}$. The pattern for double wall thickness also decreased from the butt to the top, as with the fibre length. Radially, double wall thickness for fibres from sapwood were thicker than double wall thickness for fibres from heartwood. However, the reported mean values are comparable to those reported by Sharma et al. (2015) for 6-year-old Eucalyptus hybrid trees. The fibre double wall thickness exhibited mean values that were not statistically different.

This study revealed that fibre length and double wall thickness were comparatively higher in sapwood than in heartwood. This observation suggests that sapwood could be denser than heartwood in young wood. Similar observations have been reported in literature for both young and older Eucalyptus species; 6.5-year-old trees (Pillai et al. 2013), 10-year-old trees (Tomazello 1987), 15-year-old trees (Carrillo et al. 2015), 18-year-old trees (Trevisan et al. 2013) and 37-year-old trees (Melo et al. 2018). The authors attributed their observation to cambial age as particularly related Eucalyptus species.

\subsection{Tissue proportion}

Fibre carried a proportion of $37.54 \%$ and vessel elements carried $18.60 \%$. Axial and radial parenchyma proportion were about $22 \%$ and $21 \%$ respectively (Table 3 ). Axial and radial variation in tissue proportion was recorded within trees. Study findings are compatible with studies on similar Eucalyptus hybrid species (Hu et al. 2008) and a 4.5-year-old 
Eucalyptus tereticornis (Rao et al. 2002). However, the differences reported in the present study were statistically insignificant. Generally, the radial variation, though insignificant, was a little pronounced, but only at the butt section for the tissue proportional traits. Practically, the findings suggest that the studied wood materials may be utilized irrespective of its portion on the stem. Meanwhile, the service life of the young wood could be compromised as described in Brischke et al. (2006); a direct decay-influencing factor, among others, is a material natural resistance.

\subsection{Vessel characteristics}

Generally, vessels were exclusively solitary with a diffuse porous arrangement. Vessel characteristics affect the papermaking properties of wood and other technologies like impregnability (Amidon 1981, Barauna et al. 2014, Anupam et al. 2016). The mean values for vessel area, based on cross sectional view, for the 4-year-old Eucalyptus hybrid wood is $9462 \mu \mathrm{m}^{2}$ (Table 4). Vessel area was larger in sapwood than in heartwood. Same variable increased from the butt to the middle portion of the tree before a slight decrease at the top portion. Regarding vessel quantity, the estimated mean value was approximately 14 per $\mathrm{mm}^{2}$. The top portions had highest vessel frequency followed by the butt before the middle portion. Statistically, the effect of axial and radial position on vessel quantity and size was highly significant. Practically, the results suggest that positions are important when considering the young wood for application. For instance, in cases where impregnation of preservatives is required, different portions of the stem would give different outputs.

Table 3. Mean tissue element proportion (\%), based on cross section area, for 4-year-old Eucalyptus hybrid (E. grandis $x$ E. urophylla) grown in Ghana.

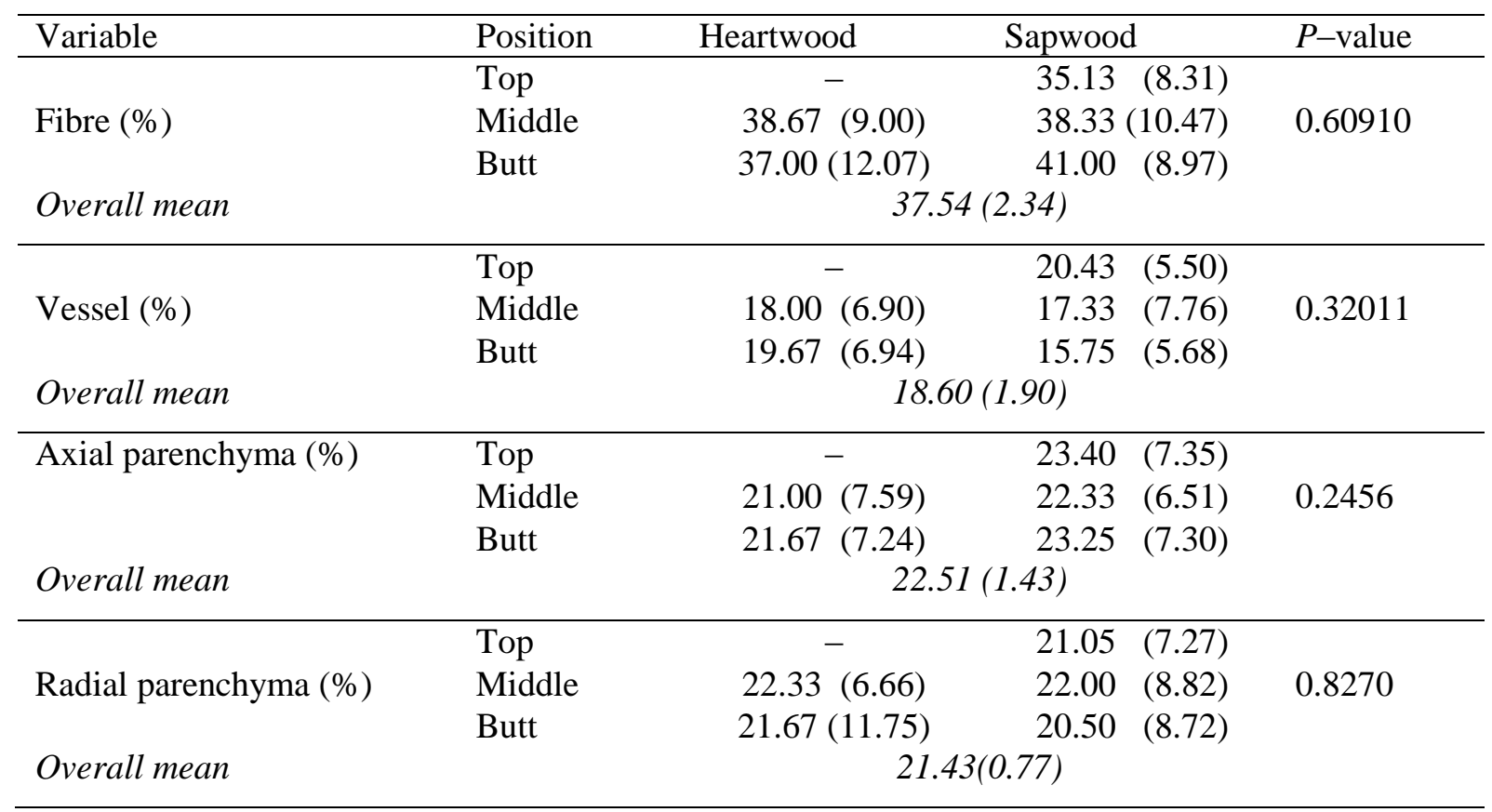

The P-values for each variable are from a two-way ANOVA run at $95 \%$ confidence interval. In parenthesis are the standard deviation of the mean values. - is used because the top portion had not developed heartwood yet. Total sampled trees $(n)=6$.

Tukey's Honest Significant Difference was employed to test where the significant difference existed among the axial positions. Regarding vessel area, the butt portion 
contributed greatly compared to the middle and the top. Conversely, for vessel frequency, the top portion contributes greatly when compared to both butt and middle. The pattern of vessel characteristics in this study conforms to earlier reports ((Taylor 1973, McKimm - Ilic 1987, Leal et al. 2003). The axial and radial variations observed in this study for vessel characteristics can be attributed to cambial age as related to eucalyptus species, and reported in literature (Leal et al. 2003, Ramírez et al. 2009, Carrillo et al. 2015).

Table 4. Mean vessel frequency per $\mathrm{mm}^{2}$ and area $\left(\mu \mathrm{m}^{2}\right)$ for 4-year-old Eucalyptus hybrid (E. grandis $x$ E. urophylla) grown in Ghana. (VA): Vessel Area; (VF): Vessel Frequency.

\begin{tabular}{|c|c|c|c|c|}
\hline Variable & Axial position & Heartwood & Sapwood & $P$-value \\
\hline & Top & - & $9503.73(3573.25)$ & \multirow{3}{*}{$1.188 \mathrm{e}-05$} \\
\hline \multirow[t]{2}{*}{$\mathrm{VA}\left(\mu \mathrm{m}^{2}\right)$} & Middle & $7816.69(3993.39)$ & $13544.41(5955.02)$ & \\
\hline & Butt & $6321.15(2729.22)$ & $9982.50(5037.37)$ & \\
\hline \multirow[t]{2}{*}{ Overall mean } & \multicolumn{4}{|c|}{$9462.04(2717.98)$} \\
\hline & Top & - & $17.70(1.93)$ & \multirow{3}{*}{$1.371 \mathrm{e}-06$} \\
\hline \multirow{2}{*}{$\mathrm{VF} / \mathrm{mm}^{2}$} & Middle & $15.00(2.36)$ & $6.60(1.51)$ & \\
\hline & Butt & $15.50(2.12)$ & $11.40(1.65)$ & \\
\hline Overall mean & \multicolumn{4}{|c|}{$13.98(4.31)$} \\
\hline
\end{tabular}

The $P$-values for each variable are from two-way ANOVA run at $95 \%$ confidence interval. In parenthesis are the standard deviations of the mean values. - is used because the top portion had not developed heartwood yet. Total sampled trees $(n)=6$.

\section{CONCLUSIONS}

This study contributes to addressing the scarce scientific literature on eucalyptus in Africa. The focus on selected anatomical properties and morphological features is an important start for the resilient species. The height, diameters, and other morphological traits identified for the 4-year-old eucalyptus hybrid wood suggest that the hybrid species could qualify for numerous applications and further related tests. The axial and radial positions within the trees had no significant effect on fibre dimensions and tissue proportions. On the contrary, axial and radial positions had significant effect on vessel frequency and area. Meanwhile, the mean values found for all variables agreed with reported values of eucalyptus species grown through seed and clones in both native and cultivated lands. Comparatively, vessels were larger in area, but fewer by frequency in sapwood than in heartwood. Additionally, both vessel area and frequency increased from butt to top portion. The findings of this study highlight some of the fundamental information needed to support efficient utilization of eucalyptus wood, especially in Ghana. In this regard, it would be helpful to conduct further research to establish the effect of age, planting distances, etc., on wood properties of the Eucalyptus hybrid species in Ghana.

Acknowledgements: The authors wish to acknowledge the Directors and managements of Asuboa Wood Treatment Company Limited and MIRO (Ghana) Forestry Limited for funding this study and granting the research team access to their plantations at Agogo. Thanks to Mr. William Hagan Brown for helping to prepare the map for the study site. 


\section{REFERENCES}

ABrÁmoff, M. D. - MAgalhães, P. J. - RAM, S. J. (2004): Image processing with Image. Biophotonics International 11 (7): 36-42.

AMIDON, T. E. (1981): Effect of the wood properties of hardwoods on kraft paper properties. Technical Association of Pulp and Paper Industry 64(3): 123-126.

ANUPAM, K. - Sharma, A. K. - LAL, P. S. - BIST, V. (2016): Physicochemical, morphological, and anatomical properties of plant fibers used for pulp and papermaking. In: Fiber Plants, Springer. pp 235-248. https://doi.org/10.1007/978-3-319-44570-0_12

BAMBER, R. (1985): The wood anatomy of eucalypts and papermaking. Technical Association of Australian and New Zealand Pulp and Paper Industry 38: 210-216.

BARAúnA, E. E. P. - LiMA, J. T. - VIEIRA, R. D. S. - SilvA, J. R. M. D. - MonTEIRO, T. C. (2014): Effect of anatomical and chemical structure in the permeability of "Amapá" wood. Cerne 20 (4): 529-534. https://doi.org/10.1590/01047760201420041501

BHAT, K. - BHAT, K. - DHAMOdARAN, T. (2007): Wood density and fiber length of Eucalyptus grandis grown in Kerala, India. Wood and Fiber Science 22 (1): 54-61.

BRISCHKE, C. - BAYERBACH, R. - OTTO, A. (2006): Decay-influencing factors: A basis for service life prediction of wood and wood-based products. Wood Material Science and Engineering 1 (34): 91-107. https://doi.org/10.1080/17480270601019658

Brito, S. A. - VidAurRe, G. B. - Oliveira, J. T. S. - Silva, J. M. G. - Oliveira, R. F. - Dias Junior, A. F. - ARANTes, M. D. C. - Moulin, J. C. - VAlin, M. - Siqueira, L. - ZauZA, E. A. V. (2021): Interaction between planting spacing and wood properties of Eucalyptus clones grown in short rotation. iForest-Biogeosciences and Forestry 14: 12-17. https://doi.org/10.3832/ifor3574-013

Brito, S. A. - VidaurRe, G. B. - Oliveira, J. T. D. S. - Silva, J. G. M. - Rodrigues, B. P. CARNEIRO, A. D. C. O. (2019): Effect of planting spacing in production and permeability of heartwood and sapwood of Eucalyptus wood. Floresta e Ambiente 26 (SPE1). https://doi.org/10.1590/2179-8087.037818

CARrillo, I. - Aguayo, M. G. - ValenZuela, S. - MendonçA, R. T. - Elissetche, J. P. (2015): Variations in wood anatomy and fiber biometry of Eucalyptus globulus genotypes with different wood density. Wood Research 60 (1): 1-10.

CARVAlHo, M. - NAHUZ, M. (2001): The evaluation of the Eucalyptus grandis $\times$ E. urophylla hybrid wood through the production of small dimension sawnwood, pulpwood and fuelwood. Scientia Forestalis 59: 61-76.

CHERELLI, S. G. (2015): Heartwood and sapwood in eucalyptus: influence of species and age on technological properties. [Dissertation] Sao Paulo state university, Faculty of Agronomic Sciences.

FRANKLIN, G. (1945): Preparation of thin sections of synthetic resins and wood-resin composites, and a new macerating method for wood. Nature 155 (3924): 51. https://doi.org/10.1038/155051a0

FujIWARA, S. - SAMESHIMA, K. - KURODA, K. - TAKAMURA, N. (1991): Anatomy and properties of Japanese hardwoods I. Variation of fibre dimensions and tissue proportions and their relation to basic density. Internation Association of Wood Anatomists 12 (4): 419-424. https://doi.org/10.1163/22941932-90000544

GITHIOMI, J. - KARIUKI, J. (2010): Wood basic density of Eucalyptus grandis from plantations in central rift valley, Kenya: variation with age, height level and between sapwood and heartwood. Tropical Forest Science, 281-286. https://www.jstor.org/stable/23616657

HARWOOD, C. (2011): New introductions-doing it right. In: proceedings of the "Farm Forestry Association conference on developing a eucalypt resource: learning from Australia and elsewhere" (Walker J. ed). University of Canterbury. Christchurch, New Zealand: Wood Technology Research Centre 43-54.

HU, J. - LIU, Y. - CHANG, S. - WU, Y. - ZHU, L. (2008): Radial variation of the micro-fibrillar angle and tissue proportion of Eucalyptus urophylla $\times$ Eucalyptus grandis families. Central South University for Forestry and Technology 28 (1): 30-34. 
LeAL, S. - Pereira, H. - Grabner, M. - Wimmer, R. (2003): Clonal and site variation of vessels in 7-year-old Eucalyptus globulus. International Association for Wood Anatomist 24 (2): 185-195. https://doi.org/10.1163/22941932-90000331

MCKIMM, R. - ILIC, Y. (1987): Characteristics of the wood of young fast-grown trees of Eucalyptus nitens Maiden with special reference to provenance variation. III. Anatomical and physical characteristics. Australian Forest Research 17 (1): 19-28.

Melo, L. E. L. - Goulart, S. L. - Guimarães, B. M. R. - Guimarães, N. R. M. - SARTORI, C. J. LIMA, J. T. (2018): Prediction of microfibril angle for Eucalyptus microcorys wood by fiber length and basic density. Maderas. Ciencia y tecnología 20 (4): 553-562. http://doi.org/10.4067/S0718-221X2018005004301

MiRANDA, I. - GOMINHO, J. - PEREIRA, H. (2009): Variation of heartwood and sapwood in 18-yearold Eucalyptus globulus trees grown with different spacings. Trees 23 (2): 367-372. http://doi.org/10.1007/s00468-008-0285-9

Moglia, J. G. - BRAVO, S. - GereZ, R. (2008): Anatomía comparada del leño de Eucalyptus camaldulensis (Myrtaceae) de dos orígenes, ensayados en Santiago del Estero [Comparative anatomy of the log of Eucalyptus camaldulensis (Myrtaceae) of two origins, tested in Santiago del Estero]. Boletín de la Sociedad Argentina de Botánica 43 (3-4): 239-246. (In Spanish)

MonteOliva, S. - SENisterRA, G. - MARLATS, R. (2005): Variation of wood density and fibre length in six willow clones (Salix spp.). International Association for Wood Anatomists 26 (2): 197202. https://doi.org/10.1163/22941932-90000111

Moore, J. R. - COWN, D. J. (2017): Corewood (juvenile wood) and its impact on wood utilisation. Current Forestry Reports, 3(2), 107-118. http://doi.org/10.1007/s40725-017-0055-2

OFORI, J. - BRENTUO, B. (2005): Green moisture content, basic density, shrinkage and drying characteristics of the wood of Cedrela odorata grown in Ghana. Tropical Forest Science 17 (2): 211-223. http://www.jstor.org/stable/23616568

Pillai, P. - PANDAlai, R. - DhamodARAn, T. - SANKARAN, K. (2013): Wood density and heartwood proportion in eucalyptus trees from intensively-managed short-rotation plantations in Kerala, India. Journal of Tropical Forest Science 25 (2): 220-227. https://www.jstor.org/stable/23617037

Plomion, C. - LePRovost, G. - StOKES, A. (2001): Wood formation in trees. Plant Physiology 127 (4): 1513-1523. https://doi.org/10.1104/pp.010816

Quilhó, T. - MiRANDA, I. - PEREIRA, H. (2006): Within-tree variation in wood fibre biometry and basic density of the urograndis eucalypt hybrid (Eucalyptus grandis $\times$ E. urophylla). International Association for Wood Anatomists 27(3): 243-254. https://doi.org/10.1163/22941932-90000152

Ramalho, F. M. G. - Pimenta, E. M. - Goulart, C. P. - De Almeida, M. N. F. - VidAurre, G. B. HEIN, P. R. G. (2019): Effect of stand density on longitudinal variation of wood and bark growth in fast-growing eucalyptus plantations. iForest-Biogeosciences and Forestry 12 (6): 527-532. https://doi.org/10.3832/ifor3082-012

Ramírez, M. - Rodríguez, J. - Peredo, M. - Valenzuela, S. - MendonÇA, R. (2009): Wood anatomy and biometric parameters variation of Eucalyptus globulus clones. Wood Science and Technology 43 (1-2): 131-141. https://doi.org/10.1007/s00226-008-0206-5

RAO, R. - ShashiKALA, S. - SREeVANi, P. - KothiYAL, V. - SARMA, C. - LAL, P. (2002): Within tree variation in anatomical properties of some clones of Eucalyptus tereticornis Sm. Wood Science and Technology 36 (3): 271-285. https://doi.org/10.1007/s00226-002-0139-3

RoQUE, R. M. (2004): Effect of management treatment and growing regions on wood properties of Gmelina arborea in Costa Rica. New Forests 28 (2): 325-330. https://doi.org/10.1023/B:NEFO.0000040965.76119.bc

SAVIDGE, R. A. (2003): Tree growth and wood quality. In: "Wood Quality and its Biological Basis" Barnett J. R. - Jeronimidis, G. eds). Blackwell Publishing, Victoria, 1-29.

SCHWEINGRUBER, F. H. (2007): Wood structure and environment: Springer Verlag, Berlin, pp. 278. https://doi.org/10.1007/978-3-540-48548-3

Sharma, S. K. - ShuKLA, S. R. - ShashiKala, S. - PoOrnima, V. S. (2015): Axial variations in anatomical properties and basic density of Eucalyptus urograndis hybrid (Eucalyptus grandis $\times \mathrm{E}$. urophylla) clones. Forestry Research 26 (3): 739-744. https://doi.org/10.1007/s11676-015-0080-6

TARDIF, J. C. - CONCIATORI, F. (2015): Microscopic examination of wood: Sample preparation and techniques for light microscopy. In: "Plant microtechniques and protocols" (Yeung E, Stasolla C, 
Sumner M, Huang B eds). Springer, Cham, pp. 373-415. https://doi.org/10.1007/978-3-31919944-3_22

TAYLOR, F. (1973): Anatomical wood properties of South African grown Eucalyptus grandis. South African Forestry Journal 84 (1): 20-24. https://doi.org/10.1080/00382167.1973.9629286

TEAM, R. C. (2014): R: A language and environment for statistical computing. Vienna, Austria: R Foundation for Statistical Computing. Web site [online 11 november 2020] URL: http://www.Rproject.org/

TOMAZELLO, F. M. (1987): Variação radial da densidade básica e da estrutura anatômica da madeira do Eucalyptus globulus, E. pellita e E. acmenioides [Radial variation of basic density and anatomical structure of Eucalyptus globulus, E. pellita and E. acmenioides wood]. Revista, Instituto de Pesquisa Florestais 36: 35-42.

Trevisan, R. - De SouZA, J. T. - Denardi, L. - Haselein, C. R. - SANTini, E. J. (2013): Effect of thinning on the wood fibre length of Eucalyptus grandis W. Hill ex Maiden. Ciência Florestal 23 (2): 463-475.

Valle, M. L. A. - Silva, J. D. C. - LuCiA, R. M. D. - Evangelista, W. V. (2013): Retention and penetration of CCA in wood of first and second rotation of Eucalyptus urophylla ST Blake. Ciência Florestal 23: 481-490. http://hdl.handle.net/1807/45303

WHEELER, E. A. (2011): Insidewood - a Web Resource for Hardwood Anatomy. International Association for Wood Anatomists 32 (2): 199-211. https://doi.org/10.1163/22941932-90000051

Willan, P. G. A. (1951): Rapid growth of Eucalyptus in Nyasaland. Empire Forestry Review 30 (1): 77. Accessed March 14, 2020. http://www.jstor.org/stable/42602074

WiMMER, R. - DOWNES, G. M. - EvANS, R. (2002): High-resolution analysis of radial growth and wood density in Eucalyptus nitens, grown under different irrigation regimes. Annals of Forest Science 59 (5-6): 519-524. https://doi.org/10.1051/forest:2002036

WoOdS, P. V. - PESETA, O. (1996): Early growth of Eucalyptus pellita on a range of sites in Western Samoa. The Commonwealth Forestry Review 75 (4): 334-337. https://www.jstor.org/stable/42608909

YAHYA, R. - SugIYAMA, J. - SilSiA, D. - GRIL, J. (2010): Some anatomical features of an Acacia hybrid, A. mangium and A. auriculiformis grown in Indonesia with regard to pulp yield and paper strength. Tropical Forest Science 22 (3): 343-351. https://www.jstor.org/stable/23616663

Zanuncio, A. V. J. - CARVAlHo, A. G. - DAMÁsio, R. A. P. - Oliveira, B. S. - CARneiro, A. C. O. - COLODETTE, J. L. (2016): Relationship between the anatomy and drying in Eucalyptus grandis X Eucalyptus urophylla wood. Revista Árvore 40 (4): 723-729. https://doi.org/10.1590/0100$\underline{67622016000400016}$

Zobel, B. J. - Sprague, J. R. (1998): Juvenile wood in forest trees. Springer Verlag: Berlin, Germany, pp. 299.

ZoBel, B. J. - VAN BuiJTENEN, J. (1989): Wood variation-its causes and control. Springer Verlag: Berlin, Germany, pp. 363. https://doi.org/10.1007/978-3-642-74069-5 1 
